HELMINTHOLOGIA, 52, 2: 104 - 112, 2015

\title{
Digenean larvae parasitizing Ruditapes decussatus (Bivalvia) from Tunisianan coasts
}

\author{
E. DHRIF ${ }^{1}$, R. ANTAR 1 , S. ABIDLI' ${ }^{2}$ L. GARGOURI ${ }^{1}$
}

${ }^{1}$ Unité de recherche: Bioécologie et systématique évolutive, Faculté des Sciences de Tunis, Université de Tunis El Manar, 2092, Tunis,

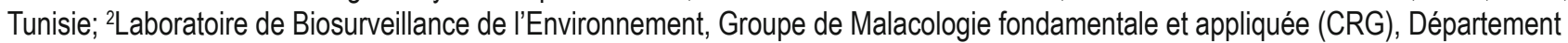
de biologie, Faculté des Sciences de Bizerte, Université de Carthage,Tunisie, E-mail: rym.antar@hotmail.fr

Article info

Received June 24, 2014

Accepted November 19, 2014

\begin{abstract}
Summary
Eleven species of trematode larvae (sporocysts and cercariae of Bucephalus labracis Paggi et Orecchia,1965 and Cercaria lata Lespes, 1857 and metacercariae of Acanthoparyphium sp. Dietz , 1909, Caecincola parvulus Marshall et Gilbert, 1905, Curtuteria australis Allison, 1979, Gymnophallus fossarum Bartoli, 1965, Gymnophallus rebecqui Bartoli, 1983, Lepocreadium pegorchis Stossich, 1901, Parazoogonus sp. Looss, 1901, Psilostomum brevicolle Creplin, 1829 and Robphildollfusium fractum Rudolphi, 1819) were found in the clam (Ruditapes decussatus) from Tunisian coasts. A part from $B$. labracis and Cercaria lata, the other trematode species were recorded for the first time in Tunisia. The examination of the frequency of recorded parasites reveals some monthly variation. This variation is statistically significant by comparing the sampling sites. These results indicate that more frequent parasites ( $G$. fossarum, Cercaria lata, Curtuteria australis and Acanthoparyphium sp.) could be considered as biological indicators making it possible to predict the capture localities of the clams. Keywords: Ruditapes decussatus; Digenea; larval stages; Tunisia
\end{abstract}

\section{Introduction}

Ruditapes decussatus (Veneridae) is a widespread bivalve in the world (from southern and western England to the Iberian Peninsula and into the Mediterranean, south to western Morocco and Senegal, west Africa) (Poppe and Goto, 1991) and on the Tunisian coasts (Zammouri-Langar, 1991; Trigui El Menif, 1995; Hamida, 2004; Attia El Hili et al., 2007; Dhraief et al., 2009). It has an important economic value since its commercialization in the domestic markets and exportation to Europe. The abundance and biomass of this benthic animal have changed significantly. In fact, this bivalve is considered a benthic organism living in the sediment-water interface, and is in constant contact with several pathogens. Among these pathogens, Digenean trematodes are the dominant macroparasites (Lauckner, 1983), that represent a real danger for bivalves and are often cited as a limiting factor for their production in several countries (De Montaudouin et al., 2009; Gam et al., 2008; Oie, 2006; Potasman et al., 2002). They have been described in many exploited mollusks as mussels, cockles, oysters and carpetshell clams (Bartoli, 1981; de Montaudouin et al., 2000;
Kim \& Powell 2006; Krakau et al., 2006; Thieltges et al., 2006; Thieltges \& Reise, 2006, 2007). They generally infect individuals of low immunity and may be the main reason of the phenotypic and genotypic perturbations in the host (Poulin, 1995; Poulin et al., 1998; Poulin, 2013). These disturbances are obviously involved in changing of the behavior of these bivalves (Moore, 2002; Mouritsen \& Poulin, 2003; Leung \& Poulin, 2007, 2011). R. decussatus seems to be exploited by digenean species; indeed, the trematode larval stages can use this mollusk as the first intermediate host but most of them use this bivalve as the second intermediate host (Bartoli, 1965, 1973, 1981; Hanafy et al., 1997, Gargouri Ben Abdallah, 2001; Gargouri Ben Abdallah \& Maamouri, 2005, Gargouri Ben Abdallah et al., 2009). In Tunisia, parasitological research on this shellfish has been of little attention and limited to clams from the lagoon of Tunis (Gargouri Ben Abdallah, 2001; Gargouri Ben Abdallah \& Maamouri, 2005; Gargouri Ben Abdallah et al., 2009). The aims of this work are to make an inventory of the parasite species of the clam Ruditapes decussatus within Tunisian coasts, to evaluate the changes in infection parameters with respect to months and localities and to know if these parasites can be con- 
sidered as biological indicators making it possible to predict the capture localities of the clams.

\section{Material and Methods}

\section{Sampling sites}

Three sampling sites were selected representing different environmental characteristics. The first station (Rades), has sand to sandy-mud bottom sediments, situated in northern Tunisia (Gulf of Tunis) between $36^{\circ} 47^{\prime} \mathrm{N}, 10^{\circ} 17^{\prime} \mathrm{E}$ and $33^{\circ} 26^{\prime} \mathrm{N}, 07^{\circ} 53^{\prime} \mathrm{E}$. Over the year, the water temperature fluctuated between $12.4{ }^{\circ} \mathrm{C}$ to $28.4^{\circ} \mathrm{C}$. The salinity ranged from $35.1 \mathrm{psu}$ in winter and $37.0 \mathrm{psu}$ in summer (Zarrad et al., 2003). This station is bordered on the north side by the thermal power plant and the channel of Rades, on the west side by the cities and the east side by the sea.

The other sampling sites are situated in southern Tunisia (Gulf of Gabes) between $35^{\circ} 40^{\prime} \mathrm{N}, 10^{\circ} 40^{\prime} \mathrm{E}$ and $47^{\circ} 72^{\prime} \mathrm{N}, 38^{\circ} 15^{\prime} \mathrm{E}$ (port of Sfax), $34^{\circ} 34^{\prime} \mathrm{N}, 10^{\circ} 36^{\prime} \mathrm{E}$ and $50^{\circ} 80^{\prime} \mathrm{N}, 41^{\circ} 84^{\prime} \mathrm{E}$ (Gargour). Port of Sfax is limited on the north side by Kettana Oued, east by the Mediterranean, south by Oued Hagouna and the west side of the continent where are the sources of human pollution as areas of landfill, a slaughterhouse and wastewater treatment stations. Station of Gargour is bordered on the north by the port of Sfax, on the east by the sea, on the south by Sidi Farah and west by the village of Gargour. The purification station of shellfish and factories are direct source for pollution for this site. The Gulf of Gabes is characterized by sandy, muddy, sandy-muddy, carbonated and sometimes swampy sediment (Drira, 2009). The mean temperature and salinity are $21.5^{\circ} \mathrm{C}$ and 39.83 psu respectively (Dhraief et al., 2009).

\section{Sampling and handling of clams}

Between October 2009 and October 2010, a total of 3457 Ruditapes decussatus was collected monthly from these three stations: 1734 (84 - 176 per month) specimens from Rades, 1234 (54 - 136 per month) specimens from port of Sfax and 489 (20 - 91 per month) from Gargour. This lamellibranch lives burrowed in sand and silty mud. The clam population was situated 2 to 5 $\mathrm{cm}$ above mean low water level and can go deep up to $10-20$ $\mathrm{cm}$ in the soil at very low winter temperatures. In this mollusk, the sexes are separate but the hermaphrodites can be found infrequently. Both sexes show a synchronism in gonadal development (Hamida, 2004). Sexual maturity is reached during the first year. The lifespan is variable and can reach 20 years. The clam, suspension feeder, seems to have a wide feeding spectrum (bacteria, algae, rotifers, detritus...). Its main predators are birds (gulls and oystercatcher....), fish (flounder, sea bream and triggerfish...) and invertebrates (gasteropods, crabs and starfish) (Le Treut, 1986; Fischer et al., 1987). The clams were located visually and hand picked. Back to the laboratory, the samples were placed into glass containers with filtered sea water and aerated by a diffuser. This method allows bivalves to get rid of most sand and impurities located between the gills and mantle. Afterwards, the mollusks were observed twice daily, under a stereomicroscope for the presence of naturally emitted cercariae. After two weeks, the clams were measured, weighed and dissected to detect the presence of young sporocysts or metacercariae. The site of infection and the number of each metacercariae were noted; metacercariae were excysted by coverslip pressure. Different reports on parasites in clams were used for species identification (Bartoli, 1967, 1984; Allison, 1979; Bowers et al., 1996; Skirnisson et al., 2004, Gargouri \& Maamouri 2005; Russell-Pinto et al., 2006, Gargouri et al., 2009, Fredensborg et al., 2013).

The parasitological terminology (prevalence, abundance and mean intensity) followed the definitions of Bush et al. (1997).

The significance of the variation of the values of the frequency according to the month and localities of capture was calculated based on the $X^{2}$-distance.

\section{Results and Discussion}

The digenean fauna of clams from the three sites was represented by 11 species: sporocysts and cercariae of Bucephalus labracis Paggi et Orecchia,1965 (Bucephalidae Pocket, 1907) and Cercaria lata Lespes, 1857 (Faustulidae Pocket, 1926) and 9 metacercariae: 1 Cryptogonimidae Ward, 1917 (Caecincola parvulus Marshall et Gilbert, 1905), 2 Echinostomidae Looss, 1902 (Acanthoparyphium sp. Dietz, 1909; Curtuteria australis Allison, 1979), 1 Gyliauchenidae Fuki, 1929 (Robphildollfusium fractum Rudolphi, 1819), 2 Gymnophallidae Odhner, 1905 (Gymnophallus fossarum Bartoli, 1965; Gymnophallus rebecqui Bartoli, 1983), 1 Lepocreadiidae Odhner, 1905 (Lepocreadium pegorchis Stossich, 1901), 1 Psilostomidae Looss, 1900 (Psilostomum brevicolle Creplin, 1829) and 1 Zoogonidae Odhner, 1902 (Parazoogonus sp. Looss, 1901). Nine digenean species were found in the north of Tunisia (Rades) and 6 species in each site in the south (Gargour and port of Sfax). Four species are common in all investigated localities (Cercaria lata, Acanthoparyphium sp., Curtuteria australis, Gymnophallus fossarum). Bucephalus labracis, Caecincola parvulus, Lepocreadium pegorchis, Robphildollfusium fractum, Parazoogonus sp. were only found in Rades whereas Gymnophallus rebecqui and Psilostomum brevicolle were harvested in both Gargour and port of Sfax (Table 1). The relatively low numbers of clams inspected in port of Sfax and Gargour could bias the comparison between sites.

The analysis of all parasites present in an individual host of $R u$ ditapes decussatus, revealed that most of these hosts harboured 1 $(58.80 \%)$ or $2(31.32 \%)$ and more rarely $3(7.14 \%)$ or $4(2.74 \%)$ species of parasites. These relatively poor infracommunities can be explained by the low rate of transmission or by competitive exclusions or insufficiency of resources.

The study of the distribution of digenean species within the host showed that sporocysts of $B$. labracis and Cercaria lata occupied the gonad and digestive gland and rarely the gills. Metacercariae of $G$. fossarum and $G$. rebecqui were localized between the mantle and the shell. Acanthoparyphium sp. colonized only the foot and $P$. brevicolle was restricted to the digestive gland and rarely to the gonad. Curtuteria australis invaded the digestive tract, gonad and the foot. L. pegorchis, Caecincola parvulus, $R$. fractum and Parazoogonus sp. were harvested from the gonad of clams. The segregation of ecological niches for most frequent parasites (case of Gymnophallidae and Echinostomatidae) is probably related to interspecific competition. In fact, by restricting the di- 


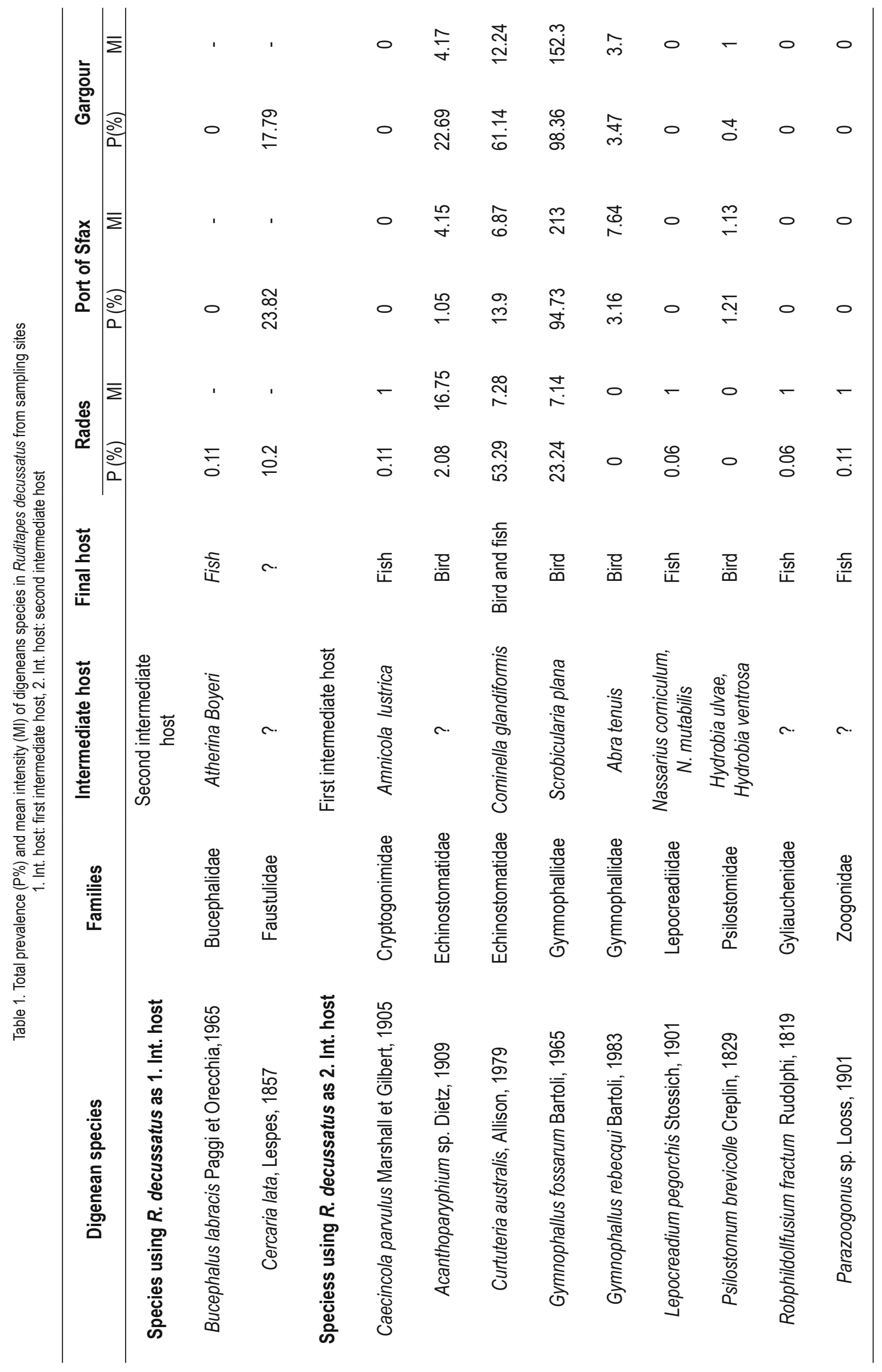




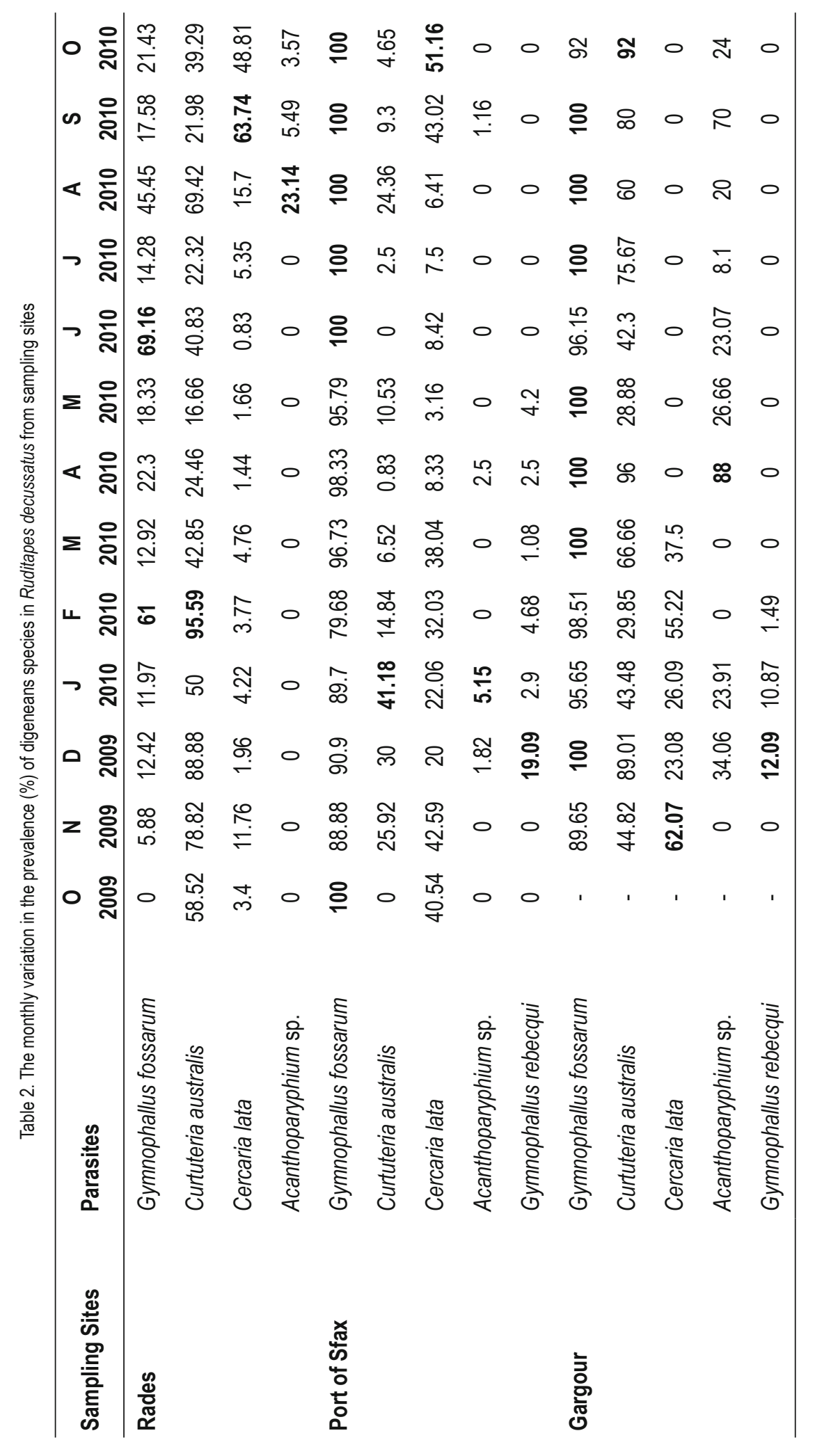


mension of the site, the parasite limits the competition with other parasite species. For sporocysts of Cercaria lata and $B$. labracis that colonize the same microbiotope they have never been found in the same bivalve; it seems that the infections of mollusk by a digenean species prevents the installation of other species and leads consequently to their exclusion. Otherwise sporocysts of Cercaria lata, and a few metacercariae of Curtuteria australis can occupy the same microbiotope (gonad). It seems that resources are sufficient if the number of metacercariae is lower. In the host's foot, Curtuteria australis can elsewhere coexists most often with Acanthoparyphium sp., a species belonging to the same subfamily Himasthlinae and having ecological similarity. Other authors (Leung and Poulin, 2007, 2011) have found that these two species occupy different microbiotopes in the host's foot; Acanthoparyphium sp. colonizes the base of the foot whereas Curtuteria australis is concentrated at the tip. They elsewhere believe that the concomitant presence of these two species is due to a change in the immune system of the host. In fact, Leung and Poulin $(2007,2011)$ thought that Curtuteria australis can act on the host genotype by changing some redundant genes considered as suppressor genes of the immune response or genes that tolerate the installation of new specimens of the same species or of other communities such as Acanthoparyphium sp. or G. fossarum.

Global values of parasitical indices of different digenean species in $R$. decussatus (Table1) show that Gymnophallus fossarum and Cercaria lata which are common in three localities, reached their highest level in the south of Tunisia (port of Sfax and Gargour). Curtuteria australis, was less frequent in the port of Sfax and showed the highest prevalence in Gargour and at lesser degree in Rades. Acanthoparyphium sp. colonized widely the shellfish collected from Gargour and had very low levels of infestation in the other two stations. G. rebecqui, harvested only in southern Tunisia, has a low infection rate. Cercaria of Bucephalus Labracis and metacercaiae of Caecincola parvulus, Lepocreadium pegorchis, Robphildollfusium fractum, Parazoogonus sp. and Psilostomum brevicolle are rare parasites. The scarcity of these parasites may be related to low frequency of hosts (intermediate or final) or non-specificity of these digeneans to Ruditapes decussatus. Apart from B. labracis, signaled by Gargouri Ben Abdallah and Maamouri (2005), others species (Caecincola parvulus, L. pegorchis, $P$. brevicolle, $R$. fractum and Parazoogonus sp.) were recorded, for the first time, in $R$. decussatus; this lamellibranch seems to be an accidental host for the last species. Indeed, metacercariae of $L$. pegorchis have been reported in other bivalve species such as Cerastoderma glauca, Paphia aurea, Parvicardium ovale, Venus verrucosa (Bartoli, 1967), metacercariae of $P$. brevicolle in Cardium edule and Mytilus edulis (Looss-Frank, 1968) and metacercariae of Caecincola parvulus in Centrarchid fish (Walter, 1941). Furthermore, Bartoli (1987) claimed that the cercariae of $R$. fractum, a species which the life cycle is still unknown, encyst on algae because the adults of the family Gyliauchenidae are harvested in herbivorous fish. Timon-David (1933, 1934 and 1936) had found the metacercariae of Zoogonidae species in the muscles of urchins (Panacentrotus lividus, Sphaenechinus granularis, Anbacia aequituberculata, Echinus acutus, Psammechinus micnotubenculatus) but never in mollusks.
The study of the monthly distribution of parasites (Tables 2 and 3) showed that $G$. fossarum and Curtuteria australis were present throughout the year at all sampling sites. Infection by G. fossarum reaching its highest level (parasitism rate reaches $100 \%$ and mean intensity 534.25 specimens) in southern Tunisia is significantly lower in Rades. The highest prevalence (69.16 \%) in this last site was recorded in June and the highest mean intensity in December (31.31 specimens). Curtuteria australis was more frequent in Rades than that of port of Sfax, with highest levels of infection in February and January respectively and reached its main prevalence in April at Gargour site. The highest mean intensity value was elsewhere noted at these last localities (27.8 specimens). However Cercaria lata has been detected only during 5 months (November 2009 - March 2010) in the site of Gargour and has been signalled in 4 seasons in the other localities. The highest values of parasitism rate were recorded in September at Rades, in October at port of Sfax and in November at Gargour. The lower frequency values were recorded in June at Rades and in May at port of Sfax. The decrease of this frequency during these two months is, undoubtedly, due to the mortality of the miracidia or the very infected clams following the increase of the temperature of water. Indeed, others authors (Evans \& Gordon, 1983; Evans, 1985) think that the life-span of infected intermediate hosts may be shorter because of higher temperatures. Moreover, Desclaux et al. (2004), in their study about the effect of digenean parasite Himasthla quissetensis on the population death of the Cockle, Cerastoderma edule, found that a high mortality rate of heavily infected cockles is recorded during periods with high temperatures. The variation of frequency according to sampling localities for these three species can be related with salinity, temperature and abundance in the prospected area of the intermediate and the final hosts allowing the completion of their heteroxenic life cycle. Acanthoparyphium $\mathrm{sp}$. has been harvested only for 3 or 4 months, respectively, at the sites of Rades and port of Sfax, and it was more common at Gargour. The highest frequency has not exceeded $5.15 \%$ in January at port of Sfax, reached $23.14 \%$ during August and $88 \%$ in April respectively at Rades and Gargour. However, the highest value of mean intensity was noted at Rades (38.8 specimens). $G$. rebecqui was absent from the site of Rades and was present only in winter at Gargour or in winter and spring at port of Sfax. The highest values of prevalence were recorded in December for two sampling localities; those of mean intensity were noted elsewhere in December at Gargour and during February at port of Sfax.

For the most frequent digenean species (Gymnophallus fossarum, Curtuteria australis, Cercaria lata, Acanthoparyphium sp., Gymnophallus rebecqui), we noted a low monthly variability for the frequencies. Except for Curtuteria australis $\left(x^{2}=15.58, d l=1\right.$, $p<0.05)$, the variations of the distribution according to the months are generally not significant statistically in the three sampling localities. However, the variation became more noticeable when we compare the sites. Indeed, for G. fossarum and Cercaria lata, the difference was significant statistically between Rades and port of Sfax $\left(X^{2}=142.86, d l=1, p<0.05\right.$ and $X^{2}=23.16, d l=1, p<0.05$ for $G$. fossarum and Cercaria lata respectively) and elsewhere between Rades and Gargour $\left(x^{2}=111.74, d l=1, p<0.05\right.$ and $X^{2}=37.38, d l=1$, $p<0.05$ for $G$. fossarum and Cercaria lata respectively). Otherwise, 


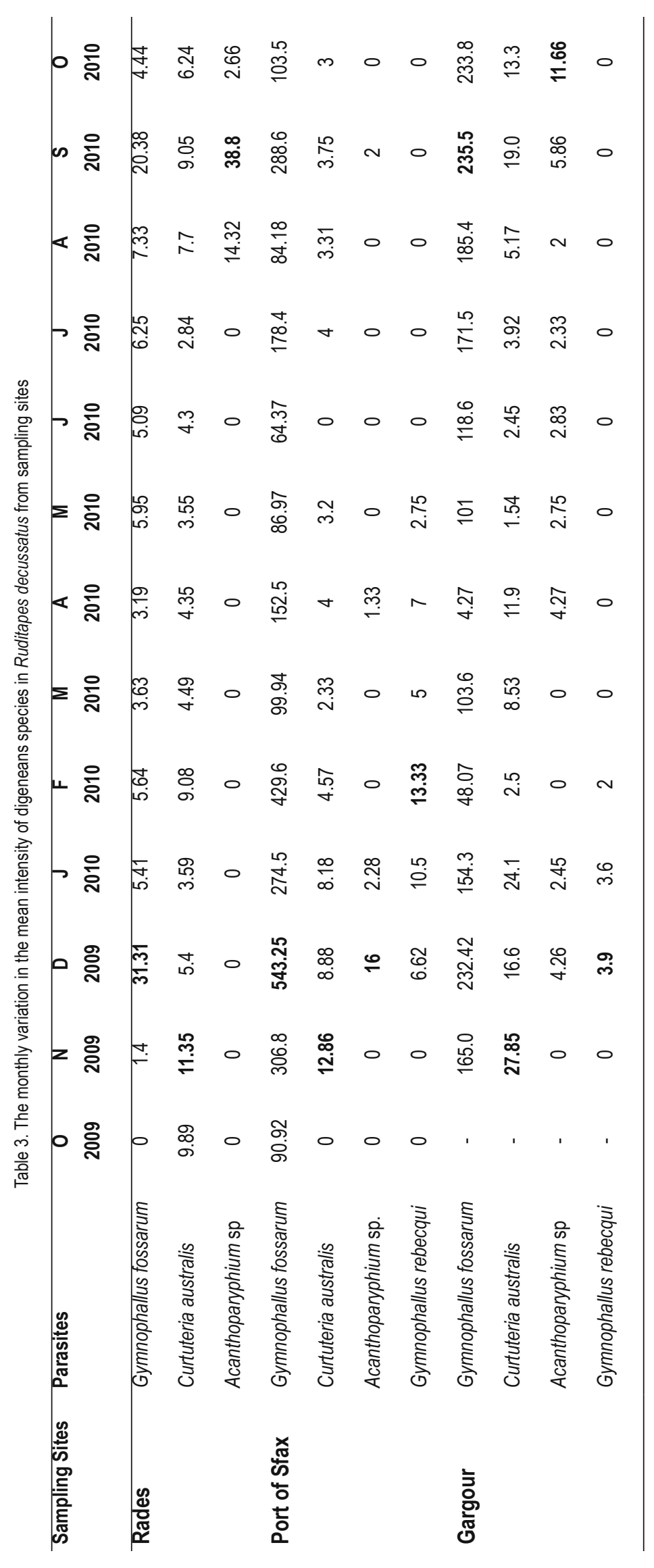


this difference was not significant between the port of Sfax and Gargour for the first species and between Rades and Gargour for the second species. Concerning Curtuteria australis, this difference was usually significant between Rades and port of $\operatorname{Sfax}\left(X^{2}=94.07\right.$, $d l=1, p<0.05$ ) and elsewhere between port of Sfax and Gargour $\left(X^{2}=68.26, d l=1, p<0.05\right)$ throughout the year. It became less significant between Rades and Gargour. For Acanthoparyphium sp, this difference was usually statistically significant between Rades and Gargour $\left(X^{2}=38.19, d l=1, p<0.05\right)$ and between the port of Sfax and Gargour $\left(X^{2}=35.42, d l=1, p<0.05\right)$ whereas it was not significant between Rades and port of Sfax. No significant difference was found between the two localities of harvest (Port of Sfax and Gargour) for G. rebecqui. So if we examine the variations of the distribution according to the sampling localities of the most frequent parasite ( $G$. fossarum, Cercaria lata, Curtuteria australis and Acanthoparyphium sp.) it is possible to consider them as biological indicators of clams stocks. We think that parasitic fauna could be used to predict the capture area for unknown samples. This result allows us to control the harvesting of shellfish from polluted sites such as the port of Sfax where fishing is prohibited. Parasites were elsewhere used for distinction of fish stocks in the countries of the northern Mediterranean coast (Arthur \& Albert, 1993; Margolis, 1993; Mackenzie, 2002; Power et al., 2005; Timi, 2007).

The digenean fauna of clams has been the subject of research in the lagoon of Tunis (Gargouri Ben Abdallah, 2001). The comparison of the digenean fauna from this lagoon with other from Tunisian coasts (Rades, port of Sfax and Gargour) showed a low diversity. Only 3 species were harvested in this lagoon (Bucephalus labracis, Cercaria lata, Lasiotocus longicystis). The last species seems to be specific to the lagoon of Tunis and the others are common in all prospected Tunisian localities. The digenean fauna of clams from the Tunisian coasts compared to that of the Arcachon Bay (Dang, 2009, Dang et al., 2009) showed that in our coasts the diversity is higher. $R$. decussatus from Arcachon Bay is colonized only with 4 species (Curtuteria arguinae, Himasthla sp., M. fossarum, unknown metacercariae). Compared to Ruditapes philippinarum from Arcachon Bay (Dang, 2009) and from the French Atlantic shore (Lassalle et al., 2007), $R$. decussatus from our coasts is elsewhere more infected; manila clams were respectively infected only by 3 species (Curtuteria arguinae and Himasthla continua, Psilostomum brevicole) and 5 species (Himasthla quissetensis, $H$. interrupta, $H$. elongate, Curtuteria arguinae, Psilostomum brevicolle). The digenean diversity of $R$. decussatus from Tunisian coasts, relatively more important, is undoubtedly related to the strategic situation of Tunisia, that representing a transition zone between the western and eastern Mediterranean, undergoes the influence of the Atlantic through the straits of Gibraltar and of the Red Sea via the Suez canal. The temperature, relatively higher on our coasts, can influence diversity and frequencies of the intermediate and final hosts. Furthermore, Flasch and Leborgne (1992) think that Manila clams, recently introduced to European waters, are probably free of their natural enemies.

\section{Acknowledgements}

We are grateful to Dr Magdi Tawfik Khalil from Faculty of Sciences 110 of Ain Shams University, Cairo, Egypt for his help to correct the English text.

\section{References}

Aluıson, F.R. (1979): Life cycle of Curtuteria australis n.sp. (Digenea:Echinostomatidae: Himasthlinae), intestinal parasite of the South Island pied oystercatcher. N.Z. J. Zool., 6: $13-20$

Arthur, J.R., Albert, E. (1993): Use of parasites for separating stocks of Greenland halibut (Reinhardtius hippoglossoides) in the Canadian northwest Atlantic. Can. J. Fish. Aquat. Sci., 50 (10): 2175 - 2181. DOI: 10.1139/f93-243

Attia El Hili, H., Ben Salah, C., Ayari, W., Ben Amor, N. (2007): A descriptive study of the infestation clam (Ruditapes decussatus) with Perkinsus olseni in Lake Bizerte in Tunisia. Rapp. Comm. Int. Mer Médit., 38: 421

BARTOLI, P. (1965): Experimental development of a new metacercaria of Gymnophallid family Morozov, 1955 (Trematoda: Digenea), a parasite of marine bivalves. Extrait Bull. Soc. Zool. France, XC (5-6): 571

BARTOLI, P. (1967): Study of the life cycle of a little known trematode: Lepocreadium pegorchis (M. Stossich 1900) (Trematoda, Digenea). Ann. Parasitol. Paris, 42 (6):605 - 619

BARTOLI, P. (1973): The microbiotopes occupied by metacercariae of Gymnophallus fossarum P. Bartoli, 1965 (Trematoda, gymnophallidae) in Tapes decussatus L. Bull. Mus. Natl. Hist. Nat., 117: $335-349$

BARTOLI, P. (1981): Demographic phenomenon and intraspecific competition of Gymnophallidae Morozov at the second intermediate hosts (Trematoda, Digenea). Ann. Parasitol. Paris, 56: 33 - 44 BARTOLI, P. (1984): Distomatoses des lamellibranches marins sur le littoral méditerranéen Français. Haliotis, 14: 98 - 107

BARTOLI, P. (1987): Les Trématodes digénétiques parasites des poissons Sparidés de la Réserve Naturelle de Scandola. Trav. Sci. Parc Natur. Région. Réserv. Natur. Corse, 10: 1 - 158

Bowers, E.A., Bartoli, P., Russell-Pinto, F., James, B.L. (1996): The metacercariae of sibling species of Meiogymnophallus, including M. rebecqui comb. nov. (Digenea: Gymnophallidae), and their effects on closely related Cerastoderma host species (Mollusca: Bivalvia). Parasitol. Res., 82: $505-510$

Bush, A.O., Lafferty, K.D., LotZ, J.M., Shostak, A.W. (1997): Parasitology meets ecology on its own terms: Margolis et al. revisited. J. Parasitol., 83: 575 - 583. DOI: 10.2307/ 3284227

DANG, C. (2009): Population dynamics of Manila clams (Ruditapes philippinarum) in the Arcachon basin and consequences on the management of exploited populations. PhD thesis, France, Bordeaux: Bordeaux University

Dang, C., De Montaudouin, X., Bald, J., Lanceleur, L., Paul-Pont, I., Callz-Milly, N. (2009): Trematode parasites in the non indigenous Manila clam Ruditapes philippinarum. Hydrobiologia, 630: $139-144$

Desclaux, C., De Montaudouin, X., Bachelet, G. (2004): Cockle (Cerastoderma edule) population mortality: the role of the digenean parasite Himasthla quissetensis. Mar. Ecol. Prog. Ser., 279: 141-150

De Montaudouin, X., Kisielewski, I., Bachelet, G., Desclaux, C. 
(2000): A census of macroparasites in an intertidal bivalve community, Arcachon Bay, France. Oceanol. Acta, 23: 453 - 468. DOI: 10.1016/S0399-1784(00)00138-9

De Montaudouin, X., Thieltges, D.w., Gam, M., Krakau, M., Pina, S., Bazairi, H., Dabouineau, L., Russell-Pinto, F., Jensen, K.t. (2009): Digenean trematode species in the cockle Cerastoderma edule: identification key and distribution along the North-East Atlantic shoreline. J. Mar. Biolog. Assoc. U.K., 89: 543-556. DOI: 10.1017/ S0025315409003130

Dhraief, M.N., Hitonori, N., Zouari, M., Guergej, H., Lymayem, Y., M'rabet, R., Missaoul, H., Kraïem, M.M. (2009): Juvenile rearing of Ruditapes decussatus (L., 1758), on the foreshore of Zarat (Gulf of Gabes, Tunisia), in experimental conditions. Bull. Inst. Natl. Sci. Tech. Mer de Salammbo, 36: $93-106$

DRIRA, Z. (2009): Contribution to the understanding the operation of the Gulf of Gabes: Study of dynamic and structural characteristics of phyto-zooplankton communities in relation to environmental variability and hydrographic characteristics of coastal and ocean areas. PhD thesis, Tunisia, Sfax: Sfax University

Evans, N.A. (1985): The influence of environmental temperature upon transmission of the cercariae of Echinostoma liei (Digenea: Echinostomatidae). Parasitology, 90: 269 - 275

Evans, N.A., Gordon, D.M. (1983): Experimental studies on the transmission dynamics of the cercariae of Echinoparyphium recurvatum (Digenea: Echinostomatidae). Parasitology, 87: 167-174

Fischer, W., Bauchot, M.L., Schneider, M. (1987): Fiches FAO d'identification des espèces pour les besoins de la pêche. (Révision 1). Méditerranée et mer Noire. Zone de pêche 37. Vol. I (Végétaux et Invertébrés). FAO, Rome, 760 pp.

FLASCH, J.P., LEBORGNE, Y. (1992): Introduction in Europe, from 1972 to 1980 , of the manila clam (Tapes philippinarum) and effects on aquaculture production and natural settlement. ICES J. Mar. Sci., 194: 92 - 96

Fredensborg, B.L., Ramirez, J.J., Partida, L. (2013): Acanthoparyphium sp. and other metazoan symbionts of the American oyster, Crassostrea virginica, from South Texas. J. Parasitol., 99(6):1129 - 32. DOI: 10.1645/12-164.1

Gam, M., Bazaïrl, H., Jensen, K.t., De Montaudouin, X. (2008): Metazoan parasites in an intermediate host population near its southern border: the common cockle (Cerastoderma edule) and its trematodes in a Moroccan coastal lagoon (Merja Zerga). J. Mar. Biolog. Assoc. U.K., 88: 357 - 364. DOI: 10.1017/S0025315408000611

Gargouri Ben Abdallah, L. (2001): Les trématodes parasites de deux poissons d'intérêt commercial le loup Dicentrarchus labrax (Linnaeus, 1758) et l'anguille Anguilla anguilla (Linnaeus, 1758). Etude comparative et cycles évolutifs des espèces du genre Bucephalus. Thèse de Doctorat. Tunisie, Tunis: Faculté des Sciences de Tunis

Gargouri Ben Abdallah, L., Maamouri, F. (2002): Life cycle of Bucephalus anguillae Spakulova, Macko, Berrilli \& Dezfuli, 2002 (Digenea, Bucephalidae) parasite of Anguilla anguilla (L.). Syst. Parasitol., 53: 207 - 217

Gargouri Ben Abdallah, L., Maamouri, F. (2005): The life cycle of Bucephalus labracis (Paggi \& Orecchia, 1965) parasite of Dicentrarchus labrax. Bull. Eur. Assoc. Fish Pathol., 25: 297 - 301

Gargouri Ben Abdallah, L., Trigul El Menif, N., MaAmouri, F.
(2009): The morphology and behaviour of Cercaria lata Lespes, 1857 (Digenea, Faustulidae) from the Mediterranean clam Tapes decussata (L.). J. Helminthol., 83: 69 - 76. DOI: 101017/ S0022149X08125160

HAmIDA, L. (2004): Reproduction of Ruditapes decussatus in a natural environment (southern Tunisia) and controlled locality (experimental hatchery): relationship with the immune system. PhD thesis, France, Brest, Western Britanny University

HanAfy, M.H., Gab-Allah, A.F.A., Hassanine, R.M.E. (1997): Larval trematode (Digenea: Lepocreadiidae) infection in the gonads of the commercial bivalve Venerupis decussata from lake Timsah, Suez Canal. J. Egypt. Germ. Soc. Zool., 24: 167 - 181

KIM, Y., POWELL, E. N. (2006): Relationships among parasites and pathologies in sentinel bivalves: NOAA Status and Trends"Mussel Watch" Program. Bull. Mar. Sci., 79: 83 - 112

Krakau, M., Thieltges, D.W., Reise, K. (2006): Native parasites adopt introduced bivalves of the North Sea. Biol. Invasions, 8: 919 - 925. DOI: 10.1007/s10530-005-4734-8

Lassalle, G., De Montaudouin, X., Soudant, P., Christine, P. (2007): Parasite co-infection of two sympatric bivalves, the Manila clam (Ruditapes philippinarum) and the cockle (Cerastoderma edule) along a latitudinal gradient. Aquat. Living Resour., 20: 33 - 42. DOI: 10.1051/alr: 2007013

Le Treut, Y. (1986): La palourde. Anatomie - Biologie - Elevage - Pêche - Consommation - Inspection sanitaire. Thèse de Doctorat, France, Nantes: Ecole Nationale Vétérinaire, Université de Nantes.

Leung, T.L.F., Poulin, R. (2007): Recruitment rate of gymnophallid metacercariae in the New Zealand cockle Austrovenus stutchburyi: an experimental test of the hitch-hiking hypothesis. Parasitol. Res., 10: 281 - 287. DOI: 10.1007/s00436-007-0479-x

LEUNG, T.L.F., Poulin, R. (2011): Intra-host competition between co-infecting digeneans within a bivalve second intermediate host: Dominance by priority-effect or taking advantage of others? Int. J. Parasitol., 41: 449 - 454. DOI: 10.1016/j.jpara.2010.11.004

Loos-Frank, B. (1968). Der entwicklungzyklus von Psilostomum brevicolle (Creplin, 1829) [Syn. P. platyurum (Mühling, 1896)] (Trematoda, Psilostomatidae). Zeitschrift für Parasitenkunde, 31: $122-131$

Mackenzie, K. (2002): Parasites as biological tags in population studies of marine organisms: an update. Parasitology, 124: 153 $-163$

Margolis, L. (1993): A case of forensic parasitology. J. Parasitol., 79: 461 - 462. DOI: 10.2307/3283591

MoORE, J. (2002): Parasites and the behavior of animals. Oxford University Press, $315 \mathrm{pp}$

Mouritsen, K.N., Poulin, R. (2002): Parasitism, community structure and biodiversity in intertidal ecosystem. Parasitology, 124: 101 - 117. DOI: 10.1017/S0031182002001476

Mouritsen, K.N., Poulin, R. (2003): Parasite induced trophic facilitation exploited by a non host predator: a manipulator's nightmare. Int. J. Parasitol., 33: 1043 - 1050. DOI: 10.1016/S00207519(03)00178-4

Potasman Paz, A., Odeh, M. (2002): Infections outbreaks associated with bivalve shelfish consumption: A wordwide perspective. Clinical infectious Diseases, 35: 921 - 928. DOI: 10.1086/342330 
Poulin, R. (1995): Adaptative changes in behaviour of parasitized animals: a critical review. Int. J. Parasitol., 25: 1371 - 1383. DOI: 10.1016/0020-7519(95)00100-X

Poulin, R., HeCker, K., Thomas, F. (1998): Hosts Manipulated by One Parasite Incur Additional Costs from Infection by Another Parasite. J. Parasitol., 84 (5): 1050 - 1052

Poulin, R. (2013): Parasite manipulation of host personality and behavioural syndromes. J. Exp. Biol., 216: 18 - 26. DOI: 10.1242/ jeb.073353

Power, A.M., Balbuena, J.A., Raga, T. (2005): Parasite infracommunities as predictors of harvest location of bug (Boops boops L.): a pilot study using statistical classifiers. Fish. Res., 72: 229 - 239. DOI:10.1016/j.fishres.2004.10.001

OIE, H.K. (2006): Word organisation for animal health. Manual of Diagnostic tests for aquatic Animals. Fifth Edition, Paris, France, 265pp

Poppe, G.T., Goto, Y. (1991): European seashells: 1. (Polyplacophora, Caudoveata, Solenogastra, Gastropoda). Christa Hemmen: Wiesbaden, Germany. 352 pp

Russell-Pinto, F., Gonçalves, J.F., Bowers, E. (2006): Digenean larvae parasitizing Cerastoderma edule (Bivalvia) and Nassarius reticulatus (Gastropoda) from Ria de Aveiro, Portugal. J. Parasitol., 92: 319 - 332

Skirnisson, K., Galaktionov, K.V., Kozminsky, E.V. (2004): Factors influencing the distribution of digenetic trematode infections in a mudsnail (Hydrobia ventrosa) population inhabiting salt marsh ponds in Iceland. J. Parasitol., 90(1):50 - 9

Thieltges, D.W., ReISE, K. (2006): Metazoan parasites in intertidal cockles Cerastoderma edule from the northern Wadden Sea. J. Sea Res., 56: 284 - 293.

ThIELTGES, D.W., ReISE, K. (2007): Spatial heterogeneity in parasite infections at different spatial scales in an intertidal bivalve. Oecologia, 150: 569 - 581. DOI: 10.1016/j.seares.2006.06.002

Thieltges, D.W., Krakau, M., Andresen, H., Fottner, S., Reise, K. (2006): Macroparasite community in molluscs of a tidal basin in the Wadden Sea. Helgol. Mar. Res., 60, 307 - 316. DOI: 10.1007/ s10152-006-0046-3

TIMI, J.T. (2007): Parasites as biological tags for stock discrimination in marine fish from South American Atlantic waters. J. Helminthol., 81: 107 - 111. DOI: 10.1017/S0022149XD7726561

Timon-DAvid, J. (1933): Contribution à l'étude du cycle évolutif des Zoogonidés (Trématodes). C. R. Acad. Sci., 196: 1923 - 1924

Timon-David, J. (1934): Recherches sur les Trématodes parasites des Oursins en Méditerranée. Bull. Inst. Oceanogr., 652: 1 - 16

Timon-David, J. (1936): Sur l'évolution expérimentale des métacercaires de Zoogonus minus Looss, 1901 (Trématodes, Famille des Zoogonidae). C. R. Assoc. Franç. Avan. Sci., Marseille, 1936: $274-276$

Trigui-EL MenIF, N. (1995): Ruditapes decussatus (Linnaeus, 1758) from the Tunisian coast: biometrics, reproductive and environmental impact on the bioaccumulation of trace metals. PhD thesis, Tunisia, Tunis: Tunis II University

WALTER, S.L. (1941): Life history of Caecincola parvulus Marshall and Gilbert (Cryptogonimidae, Trematoda) and the development of its excretory system. Trans. Am. Microsc. Soc., 60 (4): $461-484$ Zarrad, R., El Abed, A., M'rabet, R., Missaoul, H., Romdhane, M. S. (2003): Distribution spatiale de l'ichtyoplancton en été et en automne et conditions environnementales dans le golfe de Tunis. Bull. Inst. Natl. Sci. Tech. Mer de Salammbo, Tunis, 30: 39 - 47

ZAmourI-LANGAR, N. (1991): Le cycle sexuel de Tapes decussatus, Linnaeus 1758 (Bivalve/Veneridae) dans le canal de Tunis. Bull. Inst. Natl. Sci. Tech. Mer de Salammbo, Tunis, 18: 5- 22 